\title{
防食のための材料選定法
}

\author{
中原正大*, 高橋 克* \\ ** 旭化成工業株式会社エンジニアリング本部材料技術グループ
}

\section{Material Selection Method for Corrosion Control}

\author{
Masao Nakahara* and Masaru Takahashi* \\ ** Engineering Administration, Asahi Chemical Industry Co., Ltd.
}

\begin{abstract}
Actual methods of material selection for corrosion control are introduced. Material selection has some steps as follows.

1. Confirmation of corrosion environments where materials are used.

2. Selection of candidates for material tests.

3. Discussion of experimental methods.

4. Experiments in laboratory (electrochemical test, immersion test)

5. Experiments in fields.

6. Decision of materials used.
\end{abstract}

Evaluation standards (for an example) of each stages are discussed. The other factors for material selection are also discussed. Actual cases of material selection for chemical plants are showed finally.

Key words: material selection, corrosion control, electrochemical test, immersion test, chemical plant.

\section{1.はじめに}

構造材料を選定する場合に，考慮すべき重要な因子と $\iota \tau$,

・機械的性質 (強度, 剛性, 硬さ, など)

・加工性 (塑性加工性, 切削性, 溶接性, など)

・コスト (コスト/重量あるいは面積,など)

を挙げることができる。

材料には金属材料を始めとして, 有機材料, 木材，七 ラミックス材料等々，多〈の種類があるが，一般的㲹考 光て，この中で上記の因子を最もバランス良く満足する 材料は金属材料であろう。しかしこの材料の弱点は， 「腐食する」ことである。このため腐食しない(正確汇は 腐食しにくい）金属材料の開発や，有機材料ライニング 技術 $(\text { 本講座 (5) })^{1)}$, 金属被覆技術 $(\text { 本講座 (7) })^{2}$ 等が研 究されてきた。近年, これらの技術の進歩, 信頼性の向 上については，めざましいものがあるが，ごく一般的に

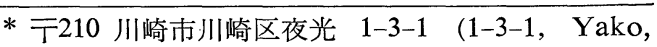
Kawasaki-ku, Kawasaki, 210 Japan)
考兄れば，「腐食しにくい金属材料を，そのままの形で 構造材料として使用できる」ことが最も望ましいのはい らまでもない。

腐食しやすい，腐食しにくい,といらことは, 使用環 境と使用される金属材料の組及合わせにより決定され る。そこで本稿では，広い範囲の腐食環境を有する化学 工業に佂ける「防食のための金属材料の選定方法」につ いて実務的な方法を概説すると共に，二，三の実例を紹 介する。

なお，ここで腐食として取り扱うものは，「湿食」であ り,いわゆる「乾食」は含まない。

\section{2. 材料選定の手順}

\section{1 材料選定のフローチャート}

図 1 亿材料選定のフローチャートを示す。

実験を行わずに材料が決定されるのは，ごく一般的な 環境で，文献中にもその耐食データが示されている場合 に限られる。このような環境です，腐食涼影する微量 の他成分が含まれる場合や，文献中の温度範囲をはずれ 


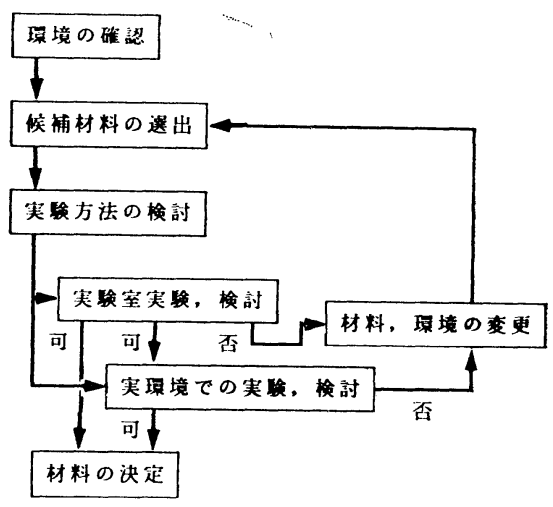

図 1 酎食材料選定のフローチャート

るような場合は, 実験を行って, 候補材料の耐食性を確 認する必要がある。

最も望ましいフローは, 実験室実験の結果を実機環境 あるいはベンチ，パイロットなどの実機に泳㜔似した 環境 (以下実環境と略) での実験により確認して, 材料を 決定するフローであるが，新規のプロセス汇対する材料 選定の場合などは実験室実験のみで材料を決定しなけれ ばならない。逆に，環境に対し耐食性が充分に期待でき る材料の場合には，実環境実験に上る確認だけで材料を 決定する場合もある。又，実験室実験では再現できない 条件だけが防食上心配される場合にも，実験室実験を行 わず，実環境での実験のみを行って，材料を決定する。

実験の結果が当初の予想に一致しない場合は, 結果を 充分に検討し，その原因を考慮する必要がある。この検 討結果を生かして, 他の候補材料を選出したり, 環境の 变更を考慮する。プロセスに大きな影響を及ぼさない範 囲での, 若干の環境の変更により, コストの安い材料が 使用可能になる場合もあり，その効果は大きい。逆に充 分に耐食性を有すると判断した材料で製作された装置で も，運転開始後著しい腐食が生ずることもある。その場 合も再度このフローにしたがって確認を行い，その原因 を明確にする必要がある。これ等の実例については, 後 述する。

\section{2 環境の確認}

「防食のための材料選定」の中の重要なステップの一 つが, 環境の確認でありその中で重要と考光られるもの を以下に記す。

\subsection{1 成 分}

主たる腐食性成分（選定対象となる材料によって異な る）が何であるかと，同様に微量成分にる注意を払ら必 要がある。例光ば, 微量の塩化物イオン, 非水溶液系に 抢ける微量の水分, 微量の酸化剂の混入などが環境の腐 食性を支配することも珍しいことではない。
又蒸溜塔のように, 成分が連続的に変化するような環 境では，必要があ机ばこれ対応するような装置を用い て実験を行わなければならない。

更に, 装置の使われ方によっては, 通常の使用条件よ りも化学洗浄時や, 停止時などのほうが腐食環境として は厳しい場合も考兄られ, 装置材料の遭遇する全ての環 境条件を把握し考慮する必要がある。

\subsection{2 温度}

腐食速度は温度が高いほど一般に大きくなる。温度が 変化する環境や，材料の裏と表で温度が異なる場合（例 えば芸熱面）などは，最高温度での腐食を見込んでおく 必要がある。

\subsection{3 酸 化 剤}

不働態皮膜を形成するような材料では, 酸化剂は一般 には防食剤として働き，不働態化しない材料では腐食を 加速する。すきま部分や, 付着物下では酸化剂は消費さ れ，不働態の維持に支障を来したり，沖合の溶液中の酸 化剂との濃度差によって, 電池を形成し, 腐食を加速し たりする。

溶存酸素も環境中で酸化剂として働くので, 腐食に影 響を与える。このため環境が大気に対し開放系であるか 閉鎖系であるかに充分注意する必要がある。

\subsection{4 流速, 固形物}

流速が速い場合や，固体粒子が同搬される場合など は，これらの機械的作用によって腐食が加速される場合 がある(エロージョン・コロージョン)。これらの因子は 重要なパラメタであるが，正確な見積りが難しく，実験 的に再現することも困難である。不働態化する材料に対 しては特に影響が大さいが，正確な評価は現場実験に頼 らざるを得ない。

\subsection{5 循環系, 流出系}

腐食によって材料から溶出するメタルイオンが腐食性 を加速したり，逆に防食したりする系もある。メタルイ オンを含む溶液が製品，㐫るいは廃液となって流出する 系では，イオンは蓄積されず，濃度は上昇しない。一方 循環系では, イオンの濃度は上昇する。硝酸環境に括け る $\mathrm{Cr}$ イオンや $\mathrm{Ti}$ イオンの挙動はこの意味で腐食を支 配している。

\subsection{6 気相, 液相, 界面}

腐食環境としては液相のみを考学がちであるが，多く の場合は気相が存在する。環境中にインヒビターが含ま れ, これによって防食されているような系では, 気相部 で㠜縮する液中にインヒビターが含まれないと，この部 分に著しい腐食が発生することとなる。また気・液界面 では腐食成分が濃縮し，腐食が加速される場合もある。

\section{3 候補材料の選出}

環境の主たるパラメタを基に文献3),方)から候補材料を 
表 1 耐食材料としての腐食速度の目安（考え方）

\begin{tabular}{|c|c|c|c|c|}
\hline 腐食速度 $(\mathrm{mm} / \mathrm{Y} \quad)$ & \begin{tabular}{|c} 
高 級材料 \\
ステンレス鎉 \\
以上上
\end{tabular} & $\begin{array}{c}\text { 低級材料 } \\
\text { 铁銅 }\end{array}$ & 塔 槽等 & 配管・部品等 \\
\hline 0.05 以下 & 传 & 侵 & 傮 & 傮 \\
\hline $0.05 \sim 0.1$ & 可 & 良 & 可 & 良 \\
\hline $0.1 \sim 0.5$ & 不可 & 可 & 不可 & 可 \\
\hline $0.5 \sim 1$ & 不可 & 一応可 & 不可 & 一応可 \\
\hline 1 以上 & 不可 & 不可 & 不可 & 不可 \\
\hline
\end{tabular}

\section{選出する。}

選定のベースとなる全面腐食速度の值については，明 確な基準はないが, $0.05 \mathrm{~mm} /$ 年以下であれば構造材料と して優れた耐食性を有していると判断され， $1 \mathrm{~mm} /$ 年以 上であればほとんどの場合使用することはできない。こ れらの值の中間の腐食速度については, 候補となる材料 のグレード, 計画される装置の種類によって, 使用可否 の基準が異なる。例学ば鋼の鋳物で造られ，容易に交 換・更新可能な装置・部品などでは, 設計必要肉厚に対 し，余肉を多く製作して拈けば， $1 \mathrm{~mm} /$ 年に近い腐食速 度でも使用可能と考兄られる。同様に, 短期間の運転の みが予定されているパイロットなどの設備に対してもこ のような考え方は成立する。逆に，材料から溶出する微 量のメタルイオンが製品の着色や触媒の被毒等の原因と なる場合は, $0.01 \mathrm{~mm} /$ 年以下でも許容できない場合があ るが，これは構造材料としての基準とは異なる基準と考 えるべきである。表 1 に構造材料としての耐食性につい て一応の目安と考えられる基準を示す。

E. ところで文献中に示されるデータは全面腐食の值であ
り，この腐食モードで寿命が支配される系においては有 効な目安となるが, 全面腐食以外の腐食損傷により寿命 が支配される系においてはこの值は意味を持たない。こ のような場合は後述するように実験方法を検討し，これ により確認を行ら必要がある。応力腐食割れの発生する 系や局部腐食の発生が知られている系についての Corrosion Data Survey ${ }^{3)}$ にも脚注の形で記述されているの で,これらを参照して候補材料を選定する。

\section{4 実験方法の検討}

環境が確認され，候補材料が選出された段階で，どの ような方法で実験を行うかについて検討を加えることと なる。

腐食に関する実験では主に二つの方法が用いられる。 電気化学的手法と浸漬試験である。浸漬試験は, 時間・ 場所的制約と実験条件の厳密性の兼放合いから, 実験室 に打ける実験と 2.1 に述べた実環境に打ける実験とに分 けられる。表 2 にこれら実験方法のそれぞれの特徵を示 于。

実際の評価にあたっては表 2 に示した三つの実験をす べて組み合わせて評価を行うことが望ましいが，現実的 には困難な場合も多い。例えば非水系溶液に対しては電 気化学実験は不可能であるし，パイロットなどの実環境 実験設備がない場合も多い。

\section{3. 腐食試験法}

材料選定を行らための, 電気化学試験と浸漬試験につ いて概説する。ただしこれらの試験法は，多分に実験を 行う研究者の特色を反映して扣り，必ずしも統一されて いない。ここでは可能な限り基本的な考え方や手法を示 すこととするが，絶対的な方法ではない。

表 2 耐食材料選定の種々の実験方法の特徵

\begin{tabular}{|c|c|c|c|}
\hline & & 長 所 & 短 所 \\
\hline \multirow[t]{2}{*}{ 実験室 } & 電気化学 & $\begin{array}{l}\text { ・短時間で腐食傾向を知る事ができる } \\
\text { ・鹰食機構を知る事ができる }\end{array}$ & $\begin{array}{l}\text { ・長時間を要する経時的な変化（付着物 } \\
\text { ・被膜形成）には対坑できない } \\
\text { ・流速. 伝熱などの影響は評価しにくい } \\
\text { ・溶液の電導性が必要 } \\
\text { ・溶液の沸点以上では特別の装置が必要 }\end{array}$ \\
\hline & 浸漬 & $\begin{array}{l}\text { ・装置．時間的な制約が少ない } \\
\text { ・溶液の電導性不要 } \\
\text { ・溶液の沸点以上でも実験ができる }\end{array}$ & $\begin{array}{l}\text { ・長時間側での液性の変化 } \\
\text { ・結果としての腐食のみを評価 } \\
\text { ・流速. 伝熱などの影響は評価できない }\end{array}$ \\
\hline 実環境 & 浸清 & $\begin{array}{l}\text { - 実際と同じ環境条件（付着物. 流速 } \\
\text { 伝熱等）の中での腐食挙動を知り得る }\end{array}$ & $\begin{array}{l}\text { ・試験片の設置や取り出しに時間的制約 } \\
\text { がある } \\
\text { ・設置方法に工夫が必要 } \\
\text { ・実環境がない場合は不可能 } \\
\text { ・取扱いにより傷が付いたりする }\end{array}$ \\
\hline
\end{tabular}




\section{1 電気化学試験}

この試験の一般的な長所, 短所は表 2 に示した通りで ある。電気化学試験は, 環境の腐食性の特徵や, 材料の 耐食性についての基本的な情報を得る上で有効である。 ここで紹介する試験は, 主に自然浸漬電位 (以下 $E_{\mathrm{c}}$ と 略) の測定と, 電位掃引法による分極特性の評価である。 これ以外にも分極抵抗法や, 定電位保持の際の電流值の 経時変化測定等種々の評価法があるがここでは省略す る。

\subsection{1 測定装置および注意点}

用いる装置は, ポテンシオスタット, 関数発生器, 電 解槽, XY レコーダー等であり, これらについては種々

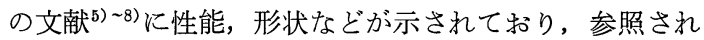
たい。試験を行う場合の主な注意点を以下に記す。

試験片には, すきまが形成されていないことが重要で あり, 旗型に切り出した物が簡便である。この場合, 端 面を含めて表面を研磨 (\#600 以上) して沶く必要がある。 又電解槽内には実環境を可能な限り忠実に再現する必要

表 3 自然電位 $\left(E_{\mathrm{c}}\right)$ の経時変化と電極反応

\begin{tabular}{|c|c|c|}
\hline 浸漬後の $E_{\mathrm{c}}$ 経時変化 & 側 & 環 \\
\hline 上昇する & 不働態が安定化する & 酸化性が増加する \\
\hline 安定である & 活性態で腐食している & $\begin{array}{l}\text { 環境の酸化・還元平衡電 } \\
\text { 位が存し, 変化しない }\end{array}$ \\
\hline 下降する & $\begin{array}{l}\text { 不働態が破罜し活 } \\
\text { 性態移行す }\end{array}$ & 酸化性が低減する \\
\hline
\end{tabular}

表 4 分極特性の分類

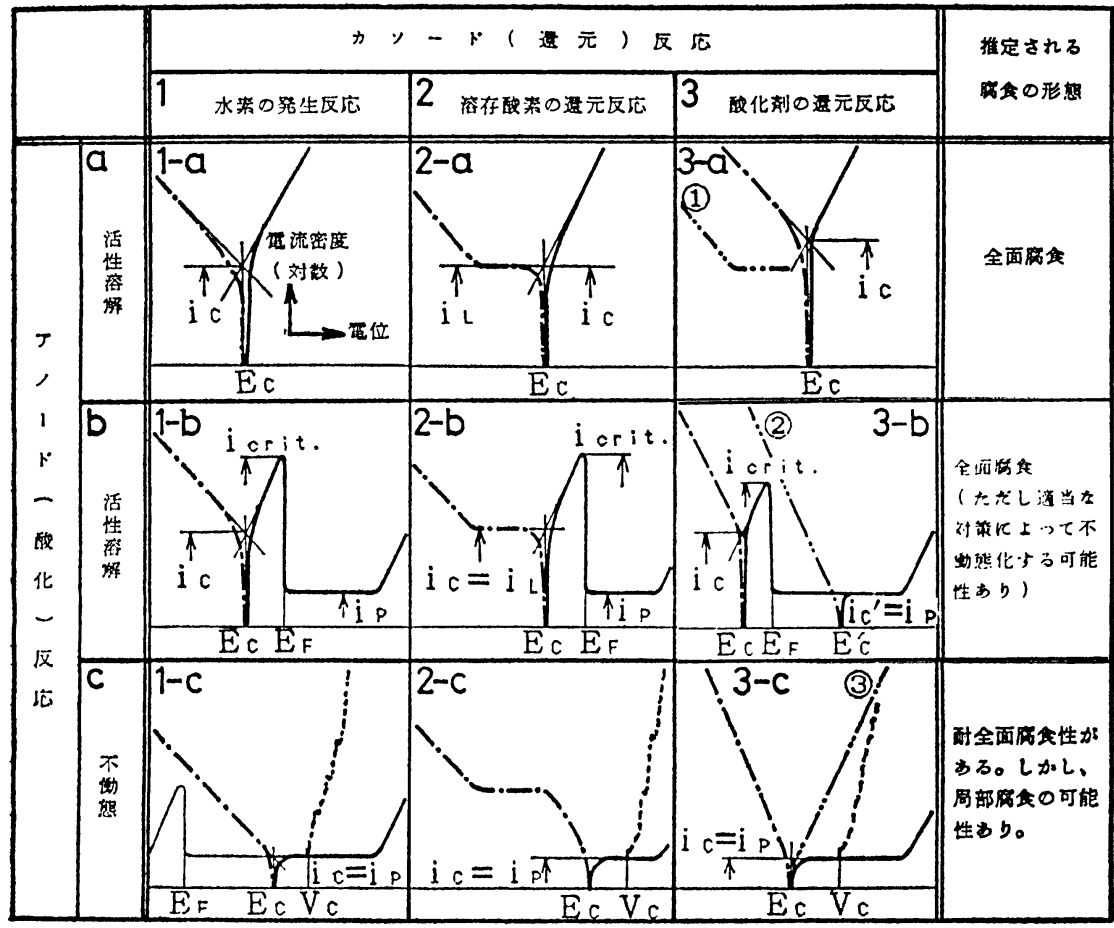

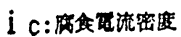

I L：溶存酸急昖散限界现流密度

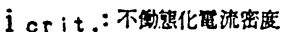

i $p$ :不知態保持西流密度

$E_{c}:$ 属食西位

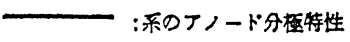

一 : 系のフノード分極特性

(1)：酸化削のない场合のカンード分梅特性

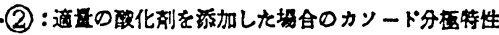

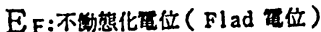

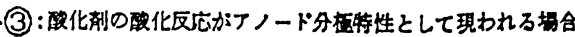

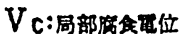


がある。このため溶液は実環境より採取するか，あるい は組成の分析結果に従って調合する。気相の雾囲気や， 温度, 液の流動等も可能な範囲で模擬する。加圧系の実 験では特殊なオートクレーブを用いた電解槽が必要とな るため, 一般には常圧, 沸点以下でガラス容器を用いて 試験を行らことが多い。

\subsection{2 測定手順}

$E_{\mathrm{c}}$ は電解槽内の環境条件 (温度など) が所定の条件に 達した後に測定を開始し, 安定するまでの経時変化を記 録する (通常数分から数時間程度)。その後, 分極特性を 測定する。 $E_{\mathrm{c}}$ の值を出発点とし，10 500 mV/分程度の 掃引速度でアノード分極曲線を求める。通常は電流密度 值が $10^{3} \sim 10^{4} \mu \mathrm{A} / \mathrm{cm}^{2}$ 程度に達するまで掃引するが, 液 抵抗が高く, この值に達しない場合には掃引を中止す る。強制的な電位を解除した後の $E_{\mathrm{c}}$ の值の経時変化を 測定しておくことは, 腐食挙動を考兄る上での有効な情 報となる。 $E_{\mathrm{c}}$ の值が初期值に戻った時点でアノード分 極と全く同様の要領でカソード分極特性を求める。もし $E_{\mathrm{c}}$ の值が初期值と著しく異なる場合は, 試験片あるい は溶液に変化が生じていることが考学られるため, これ 等を更新した後, カソード分極特性を求める。カソード 分極測定後の $E_{\mathrm{c}}$ の变化の様子も測定する。

これ等の試験後に試験片を金属顕微鏡などにより観察 し, 腐食発生の有無や, その程度を明らかにする。分極 特性から推定される腐食挙動と, この観察結果との整合
性を確認することは, 系の腐食性を知る上で重要であ る。

\subsection{3 評 価}

$\mathrm{E}_{\mathrm{c}}$ の経時変化についての考光方を表 3 に示す。上昇, 安定, 下降のそれぞれの場合について, 環境側の反応 (水素の発生反応, 溶存酸素や他の 酸化剂の 還元反応な ぞ) や材料の腐食状沉の概要 (活性態, 不働態など) が推 定される。これ等の推定は分極特性の検討により更に明 確化される。

表 4 亿分極特性の主なパターンと，これから推定され るアノード执よびカソード反応を示す。例外はあるが， 多くの分極特性は表 4 のいずれか 1 つのパターンに分類 され, 腐食挙動が推定される。前述した $E_{\mathrm{c}}$ の值や, 経 時変化, 分極後の試験片の損傷状況などを検討し, 表 4 に基づく腐食挙動の推定の妥当性を確認する。

以上の評価により, 環境側の反応抢よび材料側の反応 の特徵を明確にすることが可能となる。

\subsection{4その他の腐食損傷に対する電気化学測定法}

系の腐食挙動は 3.1.2 に示した手法により明らかにさ れるが, 1 つの応用例としてステンレス鋼の孔食電位の 測定法9)や，すき腐食の再不働態化電位の測定法 ${ }^{10)}$ どが提案されている。これ等の測定法で求められる限界 値 $\left(V_{\mathrm{c}}{ }^{\prime}, E_{\mathrm{r} \text { crevice }}\right)$ と $E_{\mathrm{c}}$ の電位を比較し, 孔食やすきま腐 食発生の危険性を評価する。例光ば $E_{\mathrm{c}}$ の值が $E_{\mathrm{c} \text { crevice }}$ より貴であれば，すきま腐食発生の可能性が高いことに

表 5 浸漬試験（主として全面腐食の評価）の注意点

\begin{tabular}{|c|c|c|c|}
\hline 項 & 目 & 注意点及, 基準 & 考 \\
\hline \multicolumn{2}{|l|}{ 表面荒さ } & $\begin{array}{l}\text { \#600 以上の 湿式研磨, 端面 } \\
\text { も含め全面もしくは部 }\end{array}$ & $\begin{array}{l}\text { 腐食を感度よく検出するため。また表面皮膜の除去 } \\
\text { (腐食発生を容易に)。 }\end{array}$ \\
\hline \multicolumn{2}{|c|}{ 脱脂, 洗浄 } & $\begin{array}{l}\text { 有機溶媒と純水で洗浄, 熱風 } \\
\text { 乾燥 }\end{array}$ & 表面の清浄化 \\
\hline \multicolumn{2}{|l|}{ 重量測定 } & $\begin{array}{l}0.1 \mathrm{mg} \text { の精度。(浸漬試験前 } \\
\text { 後に) }\end{array}$ & $\begin{array}{l}\text { 試験前後の重量変化より，腐食速度を算出。 } \\
( \pm 0.5 \mathrm{mg} \text { 程度を誤差とするととあり }\end{array}$ \\
\hline \multirow[t]{2}{*}{ 浸漬環境 } & 初期 & $\begin{array}{l}\text { 実環境の再現 (組成, 温度, } \\
\text { 液の流動, 资相需田気, 等) }\end{array}$ & 可能な範团で再現する。 \\
\hline & 試験後 & 試験期間に括仔る環境変化 & $\begin{array}{l}\text { 腐食や高温保持による液性変化の把握。pH, 溶出金 } \\
\text { 偊 } \\
\end{array}$ \\
\hline \multicolumn{2}{|l|}{ 比液量 } & (目安) $25 \mathrm{cc} / \mathrm{cm}^{2}$ & $\begin{array}{l}\text { 腐食発生による環境污染（腐食性変化）を抑制する } \\
\text { た。。 }\end{array}$ \\
\hline \multicolumn{2}{|l|}{ 試験期間 } & （目安） 100 時間以上 & 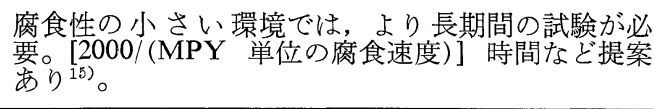 \\
\hline \multicolumn{2}{|l|}{ 試験容器 } & $\begin{array}{l}\text { 試験環境で侵食されないガラ } \\
\text { スや樹脂製 }\end{array}$ & $\begin{array}{l}\text { ガラスや, テフロンであっても, 侵食されることが } \\
\text { あり, 注意。 }\end{array}$ \\
\hline \multicolumn{2}{|c|}{ 試験片の設置 } & 他の金属との絶縁，十分な固定 & $\begin{array}{l}\text { パイロットプラントや，実機試験に扮いて注意する } \\
\text { 必要あり。 }\end{array}$ \\
\hline
\end{tabular}


表 6 材料選定を行なら際に考慮すべき損傷とその試験法

\begin{tabular}{|c|c|c|c|}
\hline 損傷形態及要因 & 試 験片形状 & 評 & 注 \\
\hline 飧面腐食および孔 & 平 & $\begin{array}{l}\text { 腐食速度, 表面観察, 侵食速 } \\
\text { 狄食の深さより) }\end{array}$ & 孔食の場合に分布や深さ \\
\hline すきま腐食 & すきま 付試験片 & $\begin{array}{l}\text { 表面持よび断面の観察（腐食 } \\
\text { の分布, 深さ) }\end{array}$ & $\begin{array}{l}\text { すきま形状, すき焉形成材, } \\
\text { すきま外の面積比 }\end{array}$ \\
\hline $\begin{array}{l}\text { 鹰力腐食割れ (水 } \\
\text { 誘起割含む) }\end{array}$ & $\begin{array}{l}\text { Uベンド試験片 } \\
\text { 溶接拘束型試片 } \\
\text { 芫荷重試験 } \\
\text { 低ひず速度試験 }\end{array}$ & 表面および断面の観察 & $\begin{array}{l}\text { 云播経路が粒内か粒界か, 寺 } \\
\text { が腐食等を起点としている } \\
\text { か }\end{array}$ \\
\hline 粒界腐食 & $\begin{array}{l}\text { 平板 (場合により } \\
\text { 溶接部を贪き試片 } \\
\text { や強制粒界腐食試 } \\
\text { 片) }\end{array}$ & $\begin{array}{l}\text { 腐食速度, 断面観察からの粒 } \\
\text { 等 }\end{array}$ & 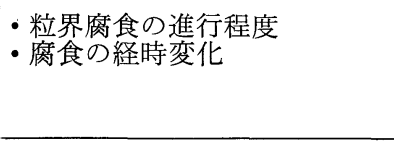 \\
\hline 溶接部 & $\begin{array}{l}\text { 溶接部を含む試験 } \\
\text { 片 }\end{array}$ & 表面および断面観察 & $\begin{array}{l}\text { ・試験片の溶接条件や初期欠陥 } \\
\text { 㤫無 } \\
\text { ・組織による耐食性の差 }\end{array}$ \\
\hline 異種金属接触 & $\begin{array}{l}\text { 金属の直接接触状 } \\
\text { 態の試験片 }\end{array}$ & $\begin{array}{l}\text { 表面及断面観察より腐食形態 } \\
\text { および性の明破 }\end{array}$ & $\begin{array}{l}\text { •実機の想定使用条件 } \\
\text { ・買種金属の面積比およ゙゙設置 } \\
\text { 方法 }\end{array}$ \\
\hline $\mathrm{Ti}, \mathrm{Ta}$ の水素吸収 & $\begin{array}{l}\text { 薄板 (例䓥ば } 0.5 \\
\mathrm{~mm} \text { 厚) 試験片 }\end{array}$ & $\begin{array}{l}\text { 表面拉よび断面観察, 水素定 } \\
\text { 量析 }\end{array}$ & 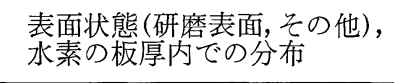 \\
\hline
\end{tabular}

なる。このような場合を含め, 電気化学試験において局 部腐食発生の可能性が示唆された場合は, 浸漬試験など により材料選択の可否を検討することが必須となる。特 にすきま腐食や孔食を起点とする応力腐食割れ発生の可 能性を評価しておくことは重要である。

\section{2 浸清試験}

浸漬試験は模擬環境 (実験室) に括祃る試験と, 実環境

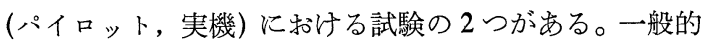
にはまず全面腐食の試験を行い,この結果で対象材料の 絞り込みを行ら。次に, 絞り込まれた材料に発生する可 能性のある他の腐食損傷の試験を行ら。

また, 特に実環境での浸漬試験切いては, 把握され ていない環境の変動要因によって,データがばら付くこ とがあり，再現性の確認が必須である。

\subsection{1 浸清試験の手順および注意点}

表 5 亿全面腐食を評価する場合の浸漬試験の注意点を 示す。他の形態の腐食を評価する場合には, 評価基準や 試験片の形状が異なるが，多くの因子は共通である。

特に注意を要するのは, 流通系でない実駼条件での液 性の変化と, 実機での実験に抢子る試験片の固定方法 （他の金属との接触，脱落の危険性）である。

\subsection{2 評 価}

試験の評価は表 1 中にも示したように, 全面腐食速度 (一般には $\mathrm{mm} /$ 年が便利) と, 試験片の表面状態の観察 によって行う。表面観察は算出された全面腐食速度の妥 当性の確認と, 重量変化に反映されにくい局部腐食など
の有無を知るために必要である。

\subsection{3 その他の腐食損傷に対する浸漬試験法}

耐食材料を選定する場合に考慮すべき腐食損傷の評価 法を表 6 に示す。場合によっては，すきまを付与した応 力腐食割れ試験や, 異種金属と接触させた状態でのチタ ンの水素吸収試験等, 複数を組み合わせた試験が必要と なる。

これらの試験の評価は対象とする損傷形態により異な る。孔食やすきま腐食はその侵食深さを基にした侵食速 度 $(\mathrm{mm} /$ 年) で評価される。粒界腐食や溶接部の腐食に ついては, 全面腐食と同様の評価が可能であるが, 実際 の腐食速度が実験值を上回る場合が多く, 実験には工夫 が必要となる11)。

粒内型の応力腐食割れや侵食速度の大きい孔食が試験 に㧤いて発生した場合, 環境の変更が不可能であれば, その材料の採用は不可能である。このような場合は材料 の変更や環境の改善を検討する必要がある。

チタンやタンタルに水素吸収が生じ，その原因が不働 態の維持に対応するもので, しかも環境の改善によって これを抑制することが困難な場合には, 水素吸収速度 $\left(\mathrm{ppm} /\right.$ 年) を推算する ${ }^{12)}$ 。この値と限界值 (場合により異 なるが，例えばチタンで $500 \mathrm{ppm}$ ) から寿命を推定し， 採用の可否を決定する。

\section{4. 材料選定上のその他の留意点}

耐食性以外にも注意すべき点がいくつかあるので以下 
に主な留意点について記す。

\section{1 コスト}

製造される製品の価値が高ければ，高級材料の使用は 可能であるが，付加価值の低、製品の場合はステンンス 鋼の使用もできない場合がある。設備の寿命や，補修な ぞに伴ら休止損失も含めたライフ・サイクル・コスト的 な考光方が重要である。

\section{2 現場施工性}

製作された設備でなんらかの補修, あるいは改造が計 画された場合，最も大きな問題は現場での 溶接性であ る。不活性ガスによる完全なシールが必要とされたり， 極度にクリーンな条件が求められたりすると, 現場での 溶接が実際上は不可能となる場合も考兄られる。又熱処 理についても同様のヶースが考兄られる。

\section{3 材料入手の難易}

特殊な材料を選定すると材料の入手に長時間を要し， 全体の計画に大きな影響を与兄る。又補修や改造に際し ても制約となる。

\section{4 材料の健全性}

試験片では良い耐食性を示したが，実際に製作された 設備では腐食が発生することがある。この原因としては 溶接や材料自身の熱処理等の不良も考兄られる。これら に対する充分な管理が必要である。

\section{5 環境の改善}

妥当なレベルの耐食材料が選定できない場合は，環境 の改善を考慮すべきである。プロセス能力に大きな影響 を与えない範囲で環境の改善（例えば，温度を下げる・ インヒビターを加える)を行うこととより，妥当なレベ ルの材料が使用可能になる場合も多い。

\section{5. 材料選定の実際}

ここでは，前述した実験手法を実際に適用した事例に ついて紹介する。これらの例では, 当初予想し得なかっ た現象が明らかとなり，試験を行うことにより適切な材 料選定が可能となった。

\section{1 不純物としての酸化㓮の効果に関する事例13)}

10\% 硫酸を主成分とする A 環境に扮いて, SUS 304 は公知のデータでは，全面腐食により使用不可であっ た。しかし実環境試験では腐食損傷は生じなかった。

この環境を分析したところ, 最大 $2000 \mathrm{ppm}$ の硝酸イ オンを含むこと, 特よび酸素分圧が最高 $3 \mathrm{~kg} / \mathrm{cm}^{2}$ に達 していることが知られた。この環境の腐食性の特徵と局 部腐食発生の可能性を検討するために, 電気化学試験を 行った。

因 2 亿不純物としての微量の硝酸 $(1000 \mathrm{ppm})$ を含む 硫酸模擬液中の $E_{\mathrm{c}}$ および，これを含まない硫酸のみの 模擬液中での SUS 304, SUS 316 の分極特性を示す。こ

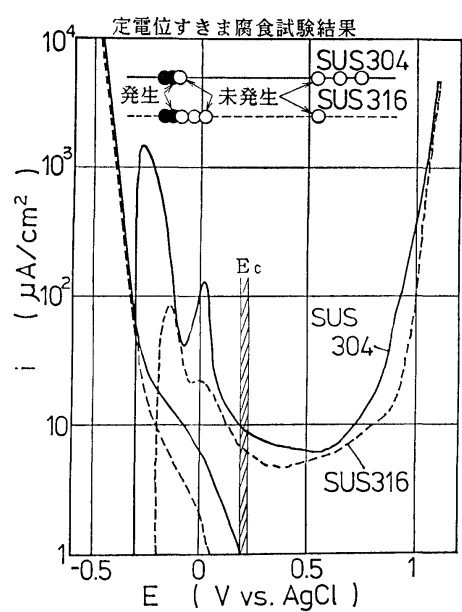

図 2 硫酸およびこれに硝酸を含む模擬液中での電 気化学試験結果

表 7 ホルムアルデヒドー儀酸模擬環境 での 腐食試 験結果

\begin{tabular}{|c|l|l|}
\hline 材料の系 & 材料 & 厚食速度 $(\mathrm{mm} / \mathrm{Y})$ \\
\hline \multirow{2}{*}{$r$} & SUS316 & 0.3 \\
\cline { 2 - 3 } & 20Cr25NiMoTi & 0.3 \\
\cline { 2 - 3 } & Has.C-276 & 0.06 \\
\hline \multirow{2}{*}{$\alpha+r$} & SUS329J2L & 0.03 \\
\cline { 2 - 3 } & SUS329J1 & 0.06 \\
\hline \multirow{2}{*}{$\alpha$} & SUS444 & 0.05 \\
\cline { 2 - 3 } & $26 \mathrm{Cr}-1 \mathrm{Mo}$ & $=0$ \\
\cline { 2 - 4 } & $30 \mathrm{Cr}-1 \mathrm{Mo}$ & $=0$ \\
\hline$\alpha$ & $\mathrm{Ti}(\mathrm{TP}-35)$ & $=0$ \\
\hline
\end{tabular}

ホルムアルデヒド； $50 \%$ 、蟻酸 $; 4 \%$ 、水溶液、 $100^{\circ} \mathrm{C} 、 100 \mathrm{Hr}$ 。

の結果から, 微量の硝酸が酸化剂として作用し,SUS 304 の不働態化を支配していることが知られた。しかしこの 環境で，すきま付試験片による定電位試験を行うと， SUS 304 では容易にすきま腐食が発生した。一方 SUS 316 でのすきま腐食は著しく軽微であった。この原因と しては, SUS 304 は活性ピーク電流密度が SUS 316 飞 比べ高いため，すきま内での酸化剈の消費が速く，より 容易にすきま腐食が発生したものと考兄られる。

この結果は浸漬試験の結果を完全に支持するるのであ った。このため実機に掠いては SUS 304 を主に採用し， すきを部はSUS 316 を採用することとした。その後こ の設備は順調に運転を継続している。

\section{2 温度の効果に関する事(例12),14)}

ホルムアルデヒド $30 \%$, 蟻酸最大 $2000 \mathrm{ppm}$, 温度 $150^{\circ} \mathrm{C}$ の環境で, SUS $329 \mathrm{~J} 1, \mathrm{~J} 2$ の溶接部に腐食が発 

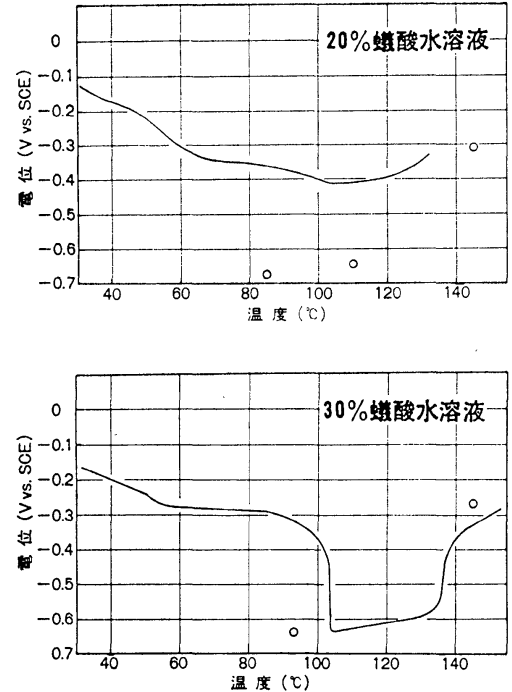

図 3 昇温過程に拈ける: Ti の浸漬電位の恋化 ○印はカソード還元後 $(-1 \mathrm{~V}$ 保持) の自然浸漬電位

生し，更新材料の選定を開始した。まず実環境での浸漬 試験を行ったところ，表 7 に示すように $\mathrm{Ti}$ および高純 度フェライト系ステンレス鋼以外の材料では何れの材料 にも腐食が発生した。

このため $\mathrm{Ti}$ が候補材と考えられたが, 滞留部でのホ ルマリンの酸化による蟻酸濃度の上昇や, 公表データで は使用可とするものが見当たらないなど，その耐食性が 懸念された。そこで蟻酸濃度を高めたホルムアルデヒド 水溶液環境で, 電気化学試験を行った。その結果図 3 に 示されるような, 昇温過程での特異な $E_{\mathrm{c}}$ の変化が認め られ, 最終的には図 4 の蟻酸濃度-温度グラフに示され るような $\mathrm{Ti}$ の不働態域が明らかとなった。

一般には温度が上昇すると腐食は加速するが，この系 では温度の上昇に伴らアノード活性ピークの増加に比 べ, 水素過電圧の減少が著しく，ある温度以上の領域で Ti は活性腐食から不働態に移るものと考えられた。

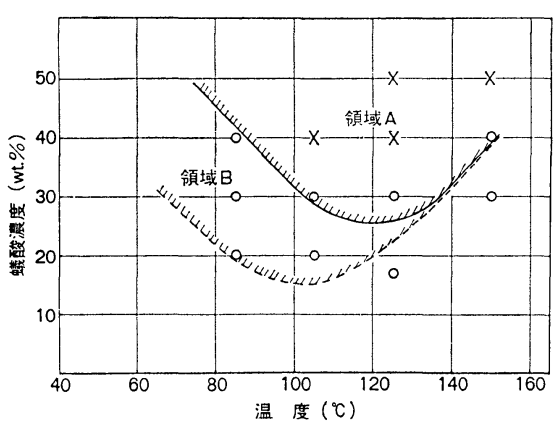

図 4 蟻酸水溶液中での $\mathrm{Ti}$ の不働態の安定性

- 電気化学試験結果：領域A (活性域), 領域 B (還 元処理後再不働態化しにくい)，その他（不働 態安定)

- 浸漬試験結果： $\bigcirc$ (不働態)，×(活性態)

これより実際の環境では，蟻酸濃度が $30 〜 40 \%$ と極 端に上昇しないかぎり, Ti の不働態は安定であり, 耐食 性を示すことが知られた。

この時点で実機中で使用されていた $\mathrm{Ti}$ 製計装部品の 破壊検査を行い, 水素吸収を評価したが, 問題とすべき 吸収は生じていないと判断され， Ti が採用された。

実機稼働後, $\mathrm{Ti}$ 薄板 $(0.5 \mathrm{~mm} t)$ のサーベイランス試 験片に水素吸収が生じたが，この原因は系内で同時に消 耗品的に用いられていたステンレス鋼との接触が原因で あることが知られ，対策が採られた。

\section{3 不健全材料の影響に関する事例 ${ }^{11)}$}

硝酸蒸気の凝縮する環境で, SUS 310 ELC $(25 \mathrm{Cr}-$ $20 \mathrm{Ni}, \mathrm{C}<0.02 \%)$ 材に短期間で損傷が発生した。この原 因を明らかにするとともに，更新材料の選定を行った。

損傷形態は粒界腐食であり，10\% 蓚酸エッチング試 験により不連続な析出物の存在が確認された。このため 損傷の発生原因は素材としての熱処理が不適切で, 耐粒 界腐食性が低下していたためと推定された。

ヒューイ試験では表 8 に示すように, この耐食性の低 下は判定不可能であった。そこで試験前に強制的に粒界

表 8 SUS 310 ELC の損傷事例での腐食試験結果（単位 $\mathrm{mm} / \mathrm{y}$ )

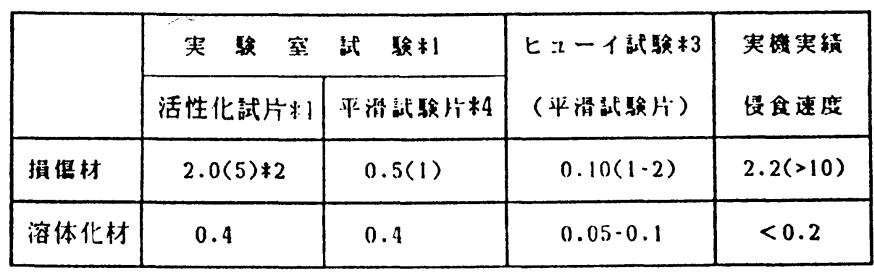

*1 站(

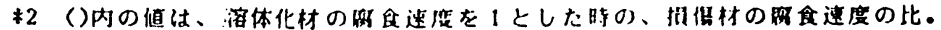

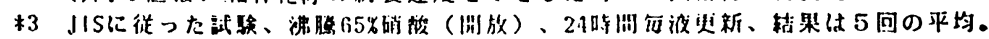

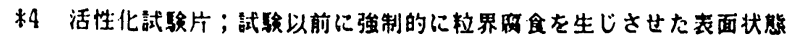


を侵食させた試験片を用い，腐食試験を行った。この結 果, 表 8 から明らかなよう飞, 同一規格の溶体化材（粒 界析出物無し) と損傷材の粒界腐食速度には約 5 倍の差 があり，前述の推定の正しいことが確認された。

更新材としては, 粒界析出物のない SUS 310 ELC を 採用した。

(1988 年 12 月 23 日受理)

\section{文献}

1）青木 茂：防食技術，37，492 (1988).

2）原田良夫：防食技術，37，618 (1988).

3) NACE: Corrosion Data Survey, Metals Section, Sixth Edition, (1985).

4）幡野佐一：“装置材料耐食表”，化学工業社, (1979).

5）北村義治：“防食技術の実際” (改訂版)，日刊工
業新聞社, 47 (1980).

6) ASM: "Metals Handbook", 9th Edition, 13, 212 (1978).

7）腐食防食協会：“防食技術便覧”，日刊工業新聞 社, 775 (1986).

8) NACE: Process Industries Corrosion, 321 (1975).

9）塩原國男：防食技術，23，293 (1974).

10）辻川茂男，久松敬弘：防食技術，29，37 (1980).

11）田村孝市，中原正大，高橋 克：第 35 回腐食防 食討論会, 287 (1988).

12) 中原正大, 高橋 克: 腐食防食 ' 88,5 (1988).

13）中原正大, 高橋 克：腐食防食 '87, 183 (1987).

14）高橋 克, 中原正大: 第 46 回腐食防食シンポジ ウム資料，39 (1983).

15) NACE: NACE standard TM-01-69 (1976 Revision). 